\title{
APLIKASI SISTEM MANAJEMEN KONTEN BAHASA MANDARIN UNTUK MENDUKUNG UJIAN HANYU SHUIPING KAOSHI
}

\author{
Darmanto $^{1}$, Yulius Hari ${ }^{2}$, Budi Hermawan ${ }^{3}$, Endang Setyawati ${ }^{4}$ \\ ${ }^{1,2,3}$ Universitas Widya Kartika, ${ }^{4}$ Universitas Kartini \\ Email: 1darmanto2@hotmail.ac.id, ${ }^{2}$ yulius.hari.s@gmail.com , ${ }^{3}$ budi_bh1@yahoo.co.id, ${ }^{4}$ endang.pattiwael@yahoo.com
}

(Naskah masuk: 9 April 2018, diterima untuk diterbitkan: 22 November 2018)

\begin{abstract}
Abstrak
Persyaratan mahasiswa yang berminat menempuh studi atau mendapatkan beasiswa pendidikan ke Perguruan Tinggi Luar Negeri dengan pengantar bahasa mandarin, adalah memiliki Sertifikat Hànyŭ Shǔ̌píng Kăoshì (HSK). Nilai lulus ujian HSK untuk mendapatkan sertifikat HSK, sering menjadi kendala calon mahasiswa meraih kesempatan studi tersebut. Saat ini, penerapan Teknologi Informasi (TI) pada bidang pendidikan dan pengajaran semakin berkembang. Melalui pemanfaatan TI yang tersedia, dengan aplikasi berbasis Content Management System (CMS), penelitian ini dilakukan untuk membantu mengatasi kendala ujian HSK. Tujuan penelitian ini untuk menghasilkan Aplikasi Sistem Manajemen Konten bahasa Mandarin yang menunjang kebutuhan ujian HSK. Aplikasinya dibuat dengan menggunakan yii framework dan berbasis web. Tahapan pembuatan aplikasi mengikuti pola Systems Development Life Cycle (SDLC) dengan metode Waterfall yang mencakup kegiatan analisa kebutuhan, perancangan, implementasi dan uji coba modul serta perawatannya. Berdasarkan hasil pengujian, secara fungsional aplikasi berjalan sesuai dengan yang diharapkan. Sementara pada analisa data kuesioner responden, dihasilkan nilai rata-rata 3,67 skala Likert. Dengan demikian aplikasi yang digunakan pengguna memberikan nilai cukup baik.
\end{abstract}

Kata kunci: Content Management System, HSK Mandarin, Web

\section{THE APPLICATION OF CONTENT MANAGEMENT SYSTEM OF MANDARIN LANGUAGE TO SUPPORT HANYU SHUIPING KAOSHI TESTS}

\begin{abstract}
One of the requirements to obtain a scholarship for educational abroad into overseas university which is using Mandarin as an academic language is the prospective applicants must have a Hànyŭ Shuíping

Kăoshi (HSK) Certificate. However, the result of their HSK exam is often becoming a constraint for the prospective students in grabbing the opportunity to get the scholarship. Meanwhile, nowadays, the application of Information Technology (IT) in the field of education is constantly widespread and developed well. So, this study was conducted to overcome the obstacles in the HSK exam, by utilizing the developement of Information Technology which is based on Content Management System (CMS). The purpose of this study is to provide a Mandarin Content Management System Application that supports the HSK exam. The application is made using the yii framework and is web-based. The stages of making the applications follow the pattern of the Systems Development Life Cycle (SDLC) with the Waterfall method which includes the analysis, design, implementation and trial of modules and its maintenance. Based on the test results, the application runs as expected. Meanwhile, the analysis of respondents' questionnaire data produced an average value of 3.67 Likert scale. Thus, the users who use this application give quite good results.
\end{abstract}

Keywords: Content Management System, Hànyǔ Shǔping Kăoshì, Web

\section{PENDAHULUAN}

Upaya pemerintah meningkatkan kualifikasi akademik dan mutu dosen dengan memberikan kesempatan studi lanjut dan beasiswa. Penyediaan beasiswa studi lanjut ke manca negara diantaranya adalah progam beasiswa yang dikelola oleh Pengelola Dana Pendidikan (LPDP). Saat ini, China menjadi salah satu tempat studi yang diminati mahasiswa S2/S3 dari negara lain. Peluang kerja, beasiswa, biaya hidup, fasilitas, bahasa, dan peringkat universitas menjadi alasan semakin banyaknya mahasiswa asing menuntut ilmu di China, termasuk mahasiswa Indonesia (Bambang, 2016) Saat kini, Pemerintah Negara China juga memberikan kesempatan luas bagi dosen di Indonesia untuk meraih beasiswa studi mulai S1 sampai jenjang S3, sebagaimana yang disampaikan oleh duta besar China untuk Indonesia (Xie, 2017).

Bagi calon mahasiswa yang berminat studi atau memperoleh beasiswa pendidikan Luar Negeri dengan pengantar kuliah bahasa Mandarin, perlu memiliki Sertifikat Hànyǔ Shǔ́píng Kăoshì (HSK) atau Chinese Proficiency Test. Disamping kemampuan berbahasa Mandarin, mahasiswa memenuhi persyaratan lulus ujian HSK pada level tertentu. HSK merupakan ujian standardisasi Republik Rakyat Tiongkok dalam kemahiran berbahasa bagi penutur bukan asli, yaitu 
mahasiswa asing atau pendatang dari luar (D. Darmanto, Hari, \& Hermawan, 2017). Ujian HSK dapat dilakukan dengan cara manual (paper-based) atau online dengan memanfaatkan komputer dan internet (internet-based). Nilai ujian HSK yang dicapai, sering kali menjadi kendala calon mahasiswa meraih kesempatan studi.

Sementara ini, cukup banyak perangkat teknologi informasi dan komunikasi yang digunakan dan dimanfaatkan untuk membantu bidang pendidikan dan pengajaran. Diantaranya adalah penelitian pengembangan game simulasi wirausaha sebagai alternatif pembelajaran di Sekolah Menengah Kejuruan (Findawati \& Sumarmi, 2015) dan aplikasi pembelajaran (elearning) bahasa Mandarin (Darmanto, Hari, \& Hermawan, 2015) ; (Y. H. Darmanto \& Hermawan, 2016). Demikian halnya, juga tersedia website yang menyajikan model tes HSK, diantaranya chinesetest.cn, chineeducenter.com. dan mandarinhouse.com. Mengacu pada sarana pendukung yang tersedia serta membantu mengatasi permasalahan pencapaian nilai lulus HSK, dalam penelitian ini dibuat aplikasi sistem manajemen konten untuk mendukung persiapan ujian HSK. Aplikasi ini juga sebagai media pembelajaran untuk membekali kemampuan berbahasa Mandarin mahasiswa S1/S2/S3. Modul aplikasi juga memfasilitasi simulasi ujian online yang dapat diakses secara berkelanjutan.

\section{METODE PENELITIAN}

Pengembangan aplikasi mengikuti pola SDLC dengan menggunakan metode air terjun (Waterfall) yang tahapannya mencakup analisa kebutuhan, perancangan, implementasi dan uji coba modul dan integrasinya, beserta perawatan sistemnya (Roger \& Bruce, 2015). Aplikasi dibangun dengan menggunakan sistem operasi Windows dan komponen utama dari paket software : Apache, MySQL dan PHP (WAMP). Kerangka penelitian secara keseluruhan dengan menggunakan pendekatan Waterfall dapat dilihat pada Gambar. 1. 2.1 Analisa Kebutuhan Aplikasi

Kebutuhan aplikasi yang dibangun meliputi kebutuhan materi, sistem dan format ujian, pengguna dan modul, serta software dan Hardware yang digunakan untuk menjalankan aplikasinya. Melalui wawancara, pengamatan dan studi literatur untuk mendapatkan data dan informasi serta proses ujian HSK. Sumber informasi ujian HSK diperoleh dari prodi pendidikan dan bahasa Mandarin UWIKA maupun dari internet. Persyaratan studi program S1/S2/S3 ke Perguruan Tinggi yang menggunakan pengantar kuliah bahasa Mandarin harus memiliki sertifikasi HSk dan paling tidak lulus tes minimal HSK level 3, 4 atau 5. Konten bahasa Mandarin dan kriteria ujian standarisasi HSK dapat dilihat pada Tabel 1, struktur ujian HSK untuk tingkat 3, 4 dan 5 (Su \& Shin, 2015).

Materi pembelajaran bahasa Mandarin untuk memahami bahan ujian HSK terdiri atas kosakata, percakapan (reading), pendengaran (listening), dan tulisan (writing) huruf Mandarin.

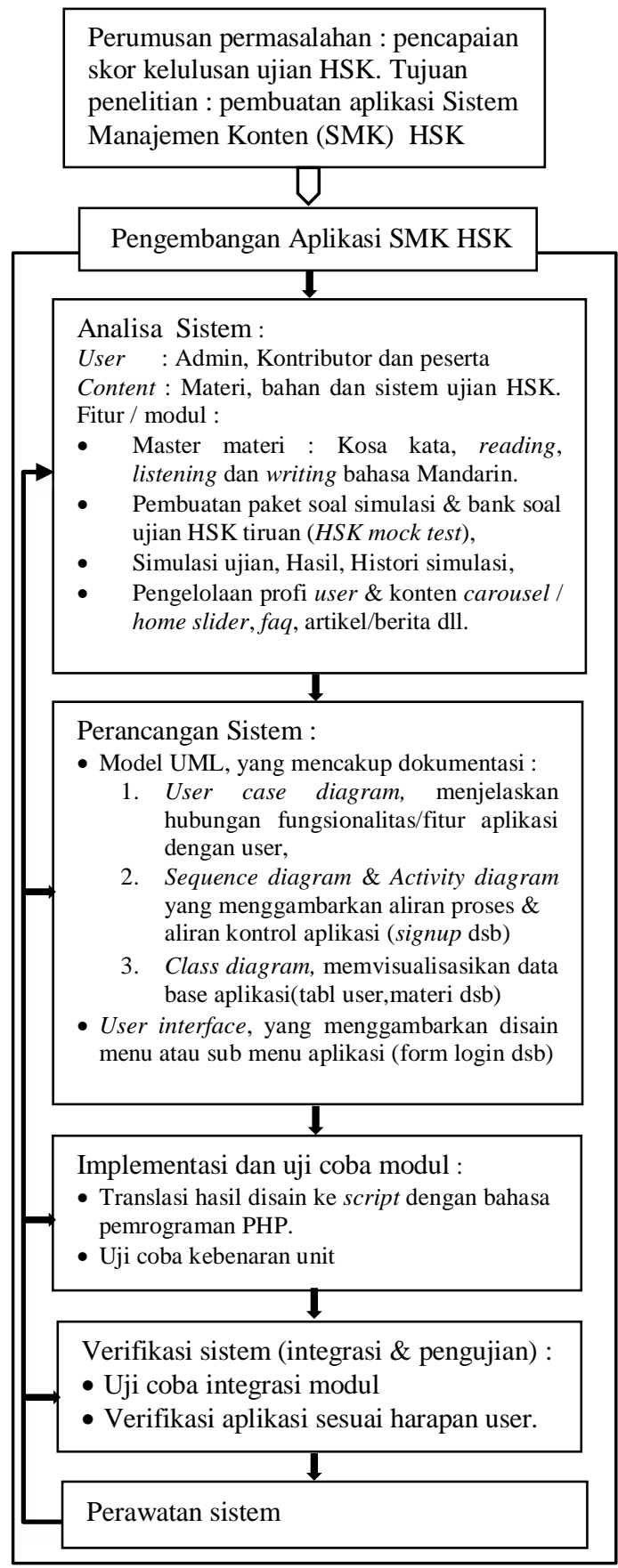

Hasil penelitian, Aplikasi SMK Bahasa

Mandarin untuk mendukung Ujian HSK

Gambar 1. Skema penelitian

Bentuk soal ujian HSK meliputi soal-soal untuk memilih jawaban yang paling benar dari pertanyaan atau pernyataan yang sesuai dengan konteks pendengaran atau bacaan dalam dialog bahasa Mandarin. Tipenya berupa soal-soal Pilihan Ganda, Benar atau Salah (B/S), melengkapi kalimat dan gambar atau tanpa gambar 
sampai pada pertanyaan yang bersifat mengganti item yang hilang (cloze test).

Sedangkan untuk bagian soal menulis, mencakup menyusun kata acak menjadi kalimat yang benar, menulis karakter mandarin sesuai pinyin yang tersedia, membuat kalimat atau karangan pendek sesuai gambar dan karakter mandarin yang tersedia.

Sistem penilaian ujian HSK tingkat 3 - 5, mencakup evaluasi komponen pemahaman listening, reading dan writing, masing-masing memiliki skor maskimal 100 poin. Sehingga skor maksimum untuk tes HSK tingkat 3 sd 5, adalah 300 poin. Peserta tes dapat dinyatakan lulus ujian HSK dan mendapatkan sertifikatnya, jika berhasil mencapai nilai di atas 180 poin. Bahkan ada yang memerlukan Sertifikat HSK 4 di atas 195 atau HSK 5 di atas 180 .

Pengguna aplikasi ini terdiri dari user, kontributor dan administrator. Semua pengguna membutuhkan hak akses untuk login kesistem kecuali sebagai user biasa yang hanya melihat materi ujian. Kebutuhan pengguna aplikasi sesuai perannya dapat dilihat pada Tabel 2 .

Setiap user yang berinteraksi ke sistem dapat melalui modul yang telah disediakan dalam aplikasi ini. Modul aplikasi yang dapat diakses oleh user terdaftar, kontributor diantaranya mencakup fitur materi, artikel, simulasi, histori simulasi, serta manajemen materi, soal, konten carousel dan artikel. Sedangkan administrator sebagai pengelola aplikasi, selain modul tersebut,juga tersedia modul untuk mengelola tema, user lain dan laporannya.

Tabel 1. Struktur Ujian HSK Tingkat 3, 4 dan 5

\begin{tabular}{|c|c|c|c|c|c|}
\hline \multirow[b]{2}{*}{$\begin{array}{l}\text { Ting } \\
\text { kat }\end{array}$} & \multirow[b]{2}{*}{$\begin{array}{c}\text { Kumulatif } \\
\text { kosakata }\end{array}$} & \multicolumn{3}{|c|}{ Komponen soal ujian HSK } & \multirow{2}{*}{$\begin{array}{c}\text { Total } \\
\text { waktu } \\
\text { (menit) }\end{array}$} \\
\hline & & $\begin{array}{c}\text { Pendenga } \\
\text { ran }\end{array}$ & $\begin{array}{c}\text { Baca } \\
\text { an }\end{array}$ & $\begin{array}{l}\text { Tuli } \\
\text { san }\end{array}$ & \\
\hline 3 & 600 & 40 & 30 & 10 & 85 \\
\hline 4 & 1200 & 45 & 40 & 15 & 100 \\
\hline 5 & 2500 & 45 & 45 & 10 & 120 \\
\hline
\end{tabular}

Tabel 2. Peran dan Kebutuhan Pengguna Aplikasi

\begin{tabular}{|c|c|c|c|}
\hline No. & Pengguna & Peran & Kebutuhan \\
\hline 1 & Admin & $\begin{array}{l}\text { Pengelola atau } \\
\text { Administator } \\
\text { aplikasi yang } \\
\text { berhak untuk } \\
\text { mengakses setiap } \\
\text { modul aplikasi. }\end{array}$ & $\begin{array}{l}\text { Mengelola profil } \\
\text { user lainnya serta } \\
\text { konten HSK, } \\
\text { tema, paket \& } \\
\text { Bank soal HSK, } \\
\text { artikel, faq, Home } \\
\text { slider }\end{array}$ \\
\hline 2 & $\begin{array}{l}\text { Kontribu- } \\
\text { tor }\end{array}$ & $\begin{array}{l}\text { Penyedia materi } \\
\text { dan layanan ujian } \\
\text { HSK }\end{array}$ & $\begin{array}{l}\text { Mengelola materi } \\
\text { \& ujian HSK, } \\
\text { paket \& Bank } \\
\text { soal, simulasi } \\
\text { ujian HSK }\end{array}$ \\
\hline 3 & $\begin{array}{l}\text { User / } \\
\text { peserta } \\
\text { ujian }\end{array}$ & $\begin{array}{l}\text { Peserta terdaftar } \\
\text { berhak atas simula } \\
\text { si ujian HSK } \\
\text { tiruan dan peserta } \\
\text { biasa hanya bisa } \\
\text { melihat materinya }\end{array}$ & $\begin{array}{l}\text { Melakukan } \\
\text { registrasi, } \\
\text { mendapat materi } \\
\text { \& ujian HSK serta } \\
\text { memperoleh hasil } \\
\text { \& histori simulasi } \\
\text { ujiannya. }\end{array}$ \\
\hline
\end{tabular}

Identfikasi perangkat keras (hardware) dan perangkat lunak (software) untuk menjalankan aplikasi ditentukan spesifikasinya sesuai dengan standar minimal. Kebutuhan perangkat lunak sistem server atau cloud dan perangkat kerasnya antara lain mencakup,

- Apache server with PHP 5.4

- $\quad$ Database server with MySQL 5.7+

- Web Service 2.0

- $\quad$ Support DAO (Data Access Object)

- Disk Storage > 512MB tergantung kebutuhan konten.

- Aplikasi Browser didukung HTML5 dengan komponen Canvas, Audio dan Video.

- RAM dengan minimum 512MB

- Browser Javascript.

- Mempunyai touch screen atau mouse.

- Mempunyai Speaker atau dapat memainkan suara.

- Konektivitas internet (direkomendasikan : 1 3Mbps)

\subsection{Perancangan aplikasi}

Mengacu pada hasil analisa kebutuhan tersebut, dibuatlah visualisasi disain aplikasinya dengan bahasa pemodelan Unified Modeling Language (UML) berbasis Object Modeling (Luthfi, 2018). Hasil model disain sistem manajemen konten bahasa Mandarin berupa perangkat dokumentasi berbasis obyek, database aplikasi, dan user interface (D. Darmanto et al., 2017).

Dalam use case pengguna dibedakan antara user biasa dan yang terdaftar. User biasa hanya diperbolehkan untuk melihat materi yang disediakan aplikasi. Pengguna biasa yang sudah berhasil melakukan proses registrasi, diijinkan login ke sistem untuk mendapatkan materi, mengikuti simulasi ujian HSK tiruan (HSK mock test), dan melihat hasilnya. Sedangkan kontributor sebagai personal yang memberikan kontribusi konten bahasa Mandarin dan pelayanan ujian HSK sekaligus sebagai evaluator hasil simulasi ujian tersebut. Seorang Administrator bertanggungjawab sebagai pengelola aplikasi, materi, tema, manajemen soal dan user lainnya. Diagram use case untuk ketiga aktor pengguna aplikasi dapat dilihat pada Gambar 2.

Sementara sebagai representasi dari aliran proses dalam aplikasinya diberikan pada kegiatan simulasi user untuk melakukan ujian HSK tiruan. User yang telah terdaftar melalui proses signup dapat memilih menu simulasi dan paket soal ujian sesuai dengan level yang diinginkan. Pada umumnya, setelah user menjawab seluruh soal yang tersedia dan menekan tombol submit, maka sistem akan memberikan tanggapan atas jawaban tersebut. Sistem menampilkan hasil simulasi yang merupakan skor ujian HSK tiruan yang dicapai user. Urutan aktivitas ini dapat dilihat pada diagram sequences Gambar 3. 


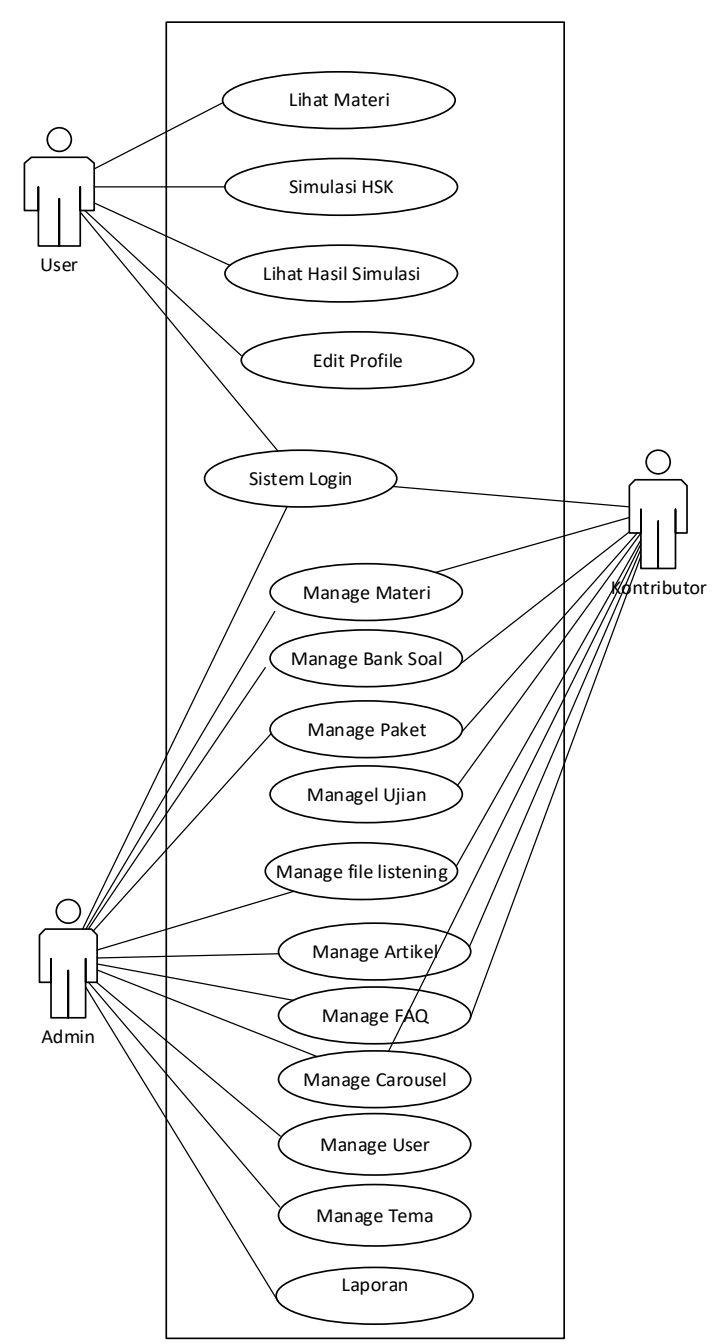

Gambar 2. Use Case Diagram SMK HSK

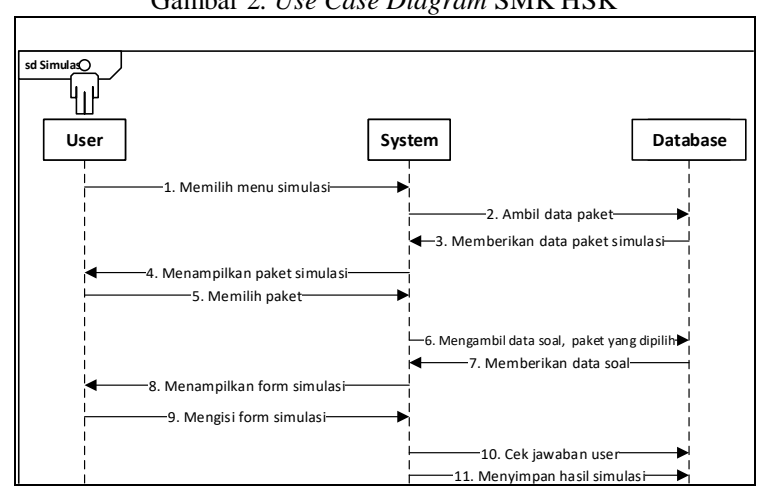

Gambar. 3. Sequense diagram untuk proses simulasi user

\section{HASIL DAN PEMBAHASAN}

\subsection{Implementasi Sistem}

Pada tahap implementasi dilakukan pembuatan kode (script) mulai dari awal berdasarkan algoritma dan perangkat dokumentasi (UML Diagram) hasil rancangan tahap sebelumnya. Pengembangan program aplikasi didasarkan pada Yii Framework (yiiframework.com, 2012).

Perangkat lunak PHP digunakan sebagai script pemrograman untuk membuat program modul dan proses update aplikasi yang dijalankan di web server Apache (Olson, 2007). Software untuk pengembangan web digunakan paket aplikasi Dreamweaver, sebagai text editornya. Sedangkan pembuatan database MySQL dengan menggunakan PHPMyAdmin.

Aplikasi yang dihasilkan dari penelitian ini berupa SMK Mandarin untuk menunjang HSK. Tampilan menu utama sebagai user interfase aplikasi dapat dijalankan melalui website online (Uwika-mandarin.com, 2017), dalam format browser desktop seperti yang terlihat pada Gambar 4.

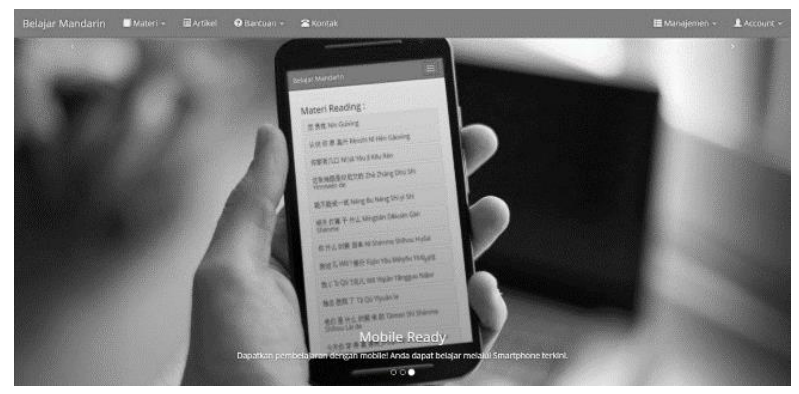

Gambar 4. Tampilan menu utama pada browser desktop

Informasi konten dalam aplikasi ini dapat berupa teks, gambar, video, suara, dokumen, laporan atau format lainnya untuk mempermudah dalam proses perubahan atau pembaruan agar lebih menarik dan mudah dipahami. Aplikasi SMK ini memiliki dua bagian kategori yaitu bagian Frontend dan Backend. Disisi Frontend mengacu pada setiap aspek desain yang berhubungan langsung dengan user interface (Ahmad, 2014)

Pada aplikasi SMK ini, bagian frontend, memiliki berbagai fitur, diantaranya modul materi untuk bahan belajar secara mandiri seperti kosa kata, reading, speaking dan writing bahasa Mandarin seperti yang terloihat pada gambar 5. Pengguna aplikasi yang terdaftar dapat mencoba modul simulasi ujian HSK yang telah dilengkapi fitur Timer sehingga pengguna dapat mengukur pemahamannya dengan mempertimbangkan waktu yang tersedia, seperti tampak pada Gambar. 6 .

Sementara pada sisi backend, seorang admin atau kontributor dapat meremajakan (update) bank soal atau paket ujian simulasi sehingga evaluasi dapat disesuaikan sesuai kebutuhan ujian yang akan ditempuh seperti yang terlihat pada Gambar 7. Disamping itu mereka dapat mengelola konten secara dinamis tampilan menu dengan meremajakan home slider melalui menu create atau update modul Carousel.

\subsection{Pengujian aplikasi}

Pengujian aplikasi menggunakan metode blackbox, yang mana pengujian dilakukan dengan mengamati hasil eksekusi melalui data uji dan memeriksa fungsi-fungsi aplikasinya secara langsung. Pengujian ini 
diantaranya untuk mengevaluasi validitas terhadap fungsionalitas aplikasi, interface, format data, akses file, kinerja, inisialisasi dan terminasi. Berdasarkan hasil pengujian aplikasi memperlihatkan bahwa semua fungsinya berjalan sesuai dengan yang diharapkan atau valid, seperti yang terlihat pada Tabel 3 .

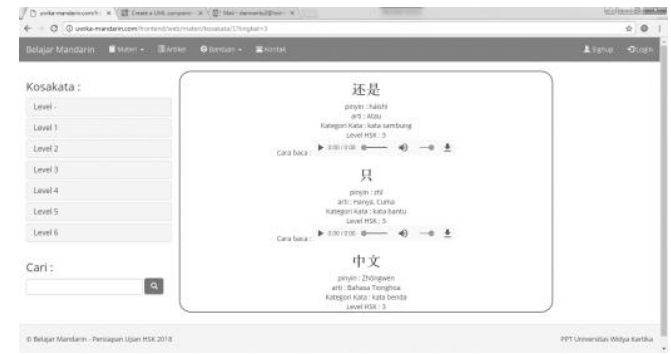

Gambar 5. Tampilan menu materi kosa kata bahan ujian HSK

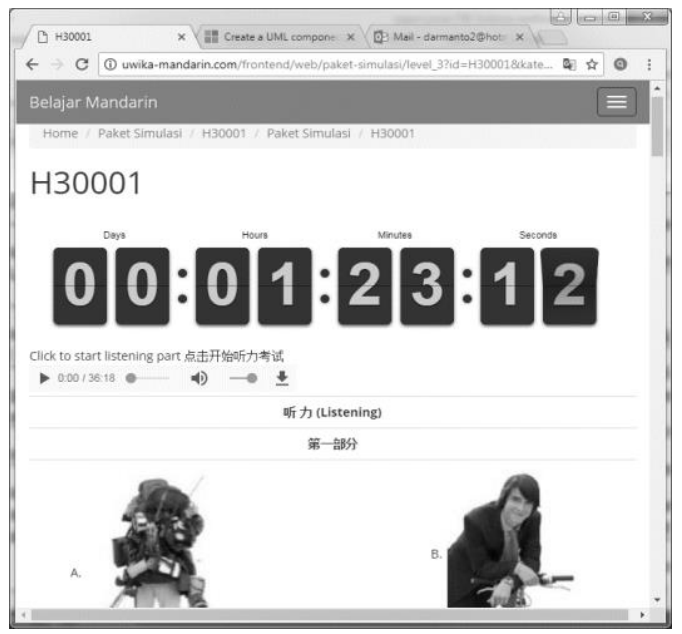

Gambar 6. Screenshot simulasi ujian HSK

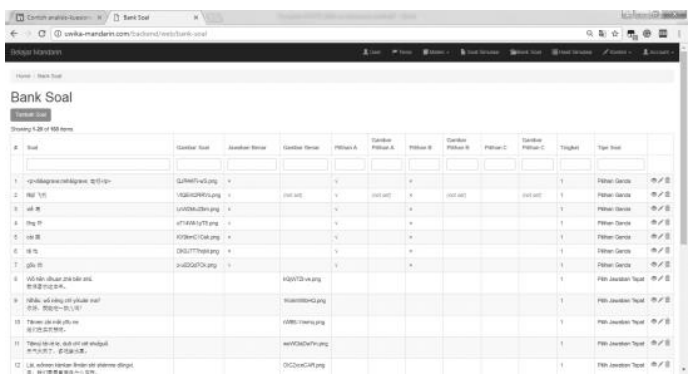

Gambar. 7. Screenshot update bank soal

Disamping pengujian aplikasi secara fungsional, juga dilakukan pengujian terhadap pengguna aplikasi yang tidak terlibat dalam pembuatannya. Dalam pengujian ini, dipilih secara acak 30 responden yang dari mahasiswa S1 dan 3 orang dosen program studi Pendidikan Bahasa Mandarin, serta beberapa mahasiswa yang mengambil sertifikasi bahasa Mandarin di Universitas Widya Kartika. Profil responden dari mahasiswa dapat dilihat pada Tabel 4.

Berdasarkan profil penguna mahasiswa menunjukkan bahwa responden perempuan dan sebagian besar sudah mengenal bahasa Mandarin cukup lama lebih dari 1 tahun sebesar $77 \%$.

Tabel 3. Daftar Uji Fungsional Aplikasi

\begin{tabular}{|c|c|c|c|}
\hline No & Fungsi & $\begin{array}{c}\text { Hasil yang } \\
\text { diharapkan }\end{array}$ & Status \\
\hline 1 & $\begin{array}{l}\text { Input field } \\
\text { (IDNama, username, } \\
\text { Password, dll) tidak } \\
\text { diisi }\end{array}$ & $\begin{array}{l}\text { Pesan field tidak boleh } \\
\text { blank, harus diisi }\end{array}$ & Valid \\
\hline 2 & Email tidak valid & Pesan email tidak valid & Valid \\
\hline 3 & Proses sign up & $\begin{array}{l}\text { Pengguna login } \\
\text { otomatis }\end{array}$ & Valid \\
\hline 4 & Proses login & Pesan sukses/gagal & Valid \\
\hline 5 & $\begin{array}{l}\text { Buat master data } \\
\text { user, tema, kosakata, } \\
\text { materi ujian HSK, } \\
\text { bank soal, paket } \\
\text { soal, Carousel, } \\
\text { artikel, faq,file } \\
\text { listening }\end{array}$ & $\begin{array}{l}\text { Pesan sukses/gagal } \\
\text { data master } \\
\text { ditambahkan }\end{array}$ & Valid \\
\hline 6 & $\begin{array}{l}\text { Update master data } \\
\text { user, tema, kosakata, } \\
\text { materi ujian HSK, } \\
\text { bank soal, paket } \\
\text { soal, Carousel, } \\
\text { artikel, faq,file } \\
\text { listening }\end{array}$ & $\begin{array}{l}\text { Pesan sukses/gagal } \\
\text { data master diperbarui }\end{array}$ & Valid \\
\hline 7 & $\begin{array}{l}\text { Hapus master data } \\
\text { user,dll }\end{array}$ & $\begin{array}{l}\text { Menampilkan dialog } \\
\text { konfirmasi }\end{array}$ & Valid \\
\hline 8 & $\begin{array}{l}\text { Upload File gambar } \\
\text { diluar extension } \\
\text {.jpg, .jpeg, .png }\end{array}$ & $\begin{array}{l}\text { Pesan hanya extension } \\
\text {.jpg, .jpeg, .png yang } \\
\text { bisa diupload }\end{array}$ & Valid \\
\hline 9 & $\begin{array}{l}\text { Upload ukuran File } \\
\text { gambar lebih dari } 1 \\
\text { MB }\end{array}$ & $\begin{array}{l}\text { Pesan file terlalu } \\
\text { besar, maksimum } 1 \\
\text { MB }\end{array}$ & Valid \\
\hline 10 & $\begin{array}{l}\text { Upload File cara } \\
\text { baca diluar extension } \\
\text {.mp3, } \\
\text {.wav, .wma }\end{array}$ & $\begin{array}{l}\text { Pesan hanya extension } \\
\text {.mp3, .wav, .wma yang } \\
\text { bisa diupload }\end{array}$ & Valid \\
\hline 11 & $\begin{array}{l}\text { Upload ukuran File } \\
\text { cara baca lebih dari } 1 \\
\text { MB }\end{array}$ & $\begin{array}{l}\text { Pesan file terlalu besar, } \\
\text { maksimum } 1 \mathrm{MB}\end{array}$ & Valid \\
\hline 12 & $\begin{array}{l}\text { Upload File } \\
\text { listening dilluar } \\
\text { extension .mp3, } \\
\text {.wav, .wma }\end{array}$ & $\begin{array}{l}\text { Pesan hanya file } \\
\text { dengan extension } \\
\text {.mp3, .wav, .wma } \\
\text { yang bisa diupload }\end{array}$ & Valid \\
\hline 13 & $\begin{array}{l}\text { File listening } \\
\text { memiliki ukuran } \\
\text { lebih dari } 20 \mathrm{MB}\end{array}$ & $\begin{array}{l}\text { Pesan file terlalu } \\
\text { besar, maksimum } 20 \\
\text { MB }\end{array}$ & Valid \\
\hline
\end{tabular}

Tabel 4. Profil Responden Aplikasi

\begin{tabular}{lccc}
\hline \multicolumn{1}{c}{ Profil pengguna } & & Jumlah & Persentasi \\
\hline \multirow{2}{*}{ Jenis kelamin } & $\mathrm{L}$ & 7 & 23 \\
& $\mathrm{P}$ & 23 & 77 \\
\hline \multirow{3}{*}{ Semester } & $2-3$ & 2 & 7 \\
& $4-5$ & 15 & 50 \\
& $6-7$ & 13 & 43 \\
\hline \multirow{2}{*}{ Lama belajar } & $<1$ tahun & 7 & 23 \\
& $1-3$ tahun & 9 & 30 \\
\hline \multirow{2}{*}{ Pernah ujian HSK } & $>3$ tahun & 14 & 47 \\
\hline \multirow{4}{*}{ Ya } & 2 & 7 \\
Kecepatan baca kosa & Tidak & 28 & 93 \\
kata & $<146$ & & \\
& kata/menit & 16 & 53 \\
& $146-166$ & & 40 \\
kata/menit & 12 & \\
\hline $\begin{array}{l}\text { Mengerti sejumlah } \\
\text { kosa kata }\end{array}$ & $>166$ kata / & & 7 \\
\hline
\end{tabular}




\begin{tabular}{ccc}
\hline Profil pengguna & Jumlah & Persentasi \\
\hline $\begin{array}{l}600-1200 \\
\text { kosa kata } \\
>1200 \text { kosa } \\
\text { kata }\end{array}$ & 11 & 37 \\
\hline
\end{tabular}

Diatas $90 \%$, responden duduk di semesetr 4 ke atas dan sebagian juga sudah mengenal kosa kata lebih dari 600 kosa kata. Bahkan sudah ada yang lulus sertifikasi HSK 4 dan HSK 5. Berdasarkan profil tersebut, mahasiswa diminta memberikan umpan balik, dari 8 item pertanyaan terkait dengan fitur dan operasional aplikasi. Sedangkan untuk kontributor dengan 5 item untuk memberikan tanggapannya mengenai pengelolaan aplikasi yang disediakan, Masing item diberi bobot berdasarkan nilai skala Likert untuk rentang 1 = sangat tidak setuju, 2 = tidak setuju, $3=$ cukup, $4=$ setuju, dan $5=$ sangat setuju bahwa aplikasi mudah dioperasikan dan sesuai kebutuhan. Diantara item yang perlu mendapatkan tanggapan dari kontributor mengenai aplikasinya adalah menyangkut pengelolaan materi, paket soal, bank soal, konten SMK serta aplikasi keseluruhan. Disamping juga kemudahan proses registrasi dan update profilnya sendiri. Berdasarkan umpan balik yang diberikan responden sejumlah 30 mahasiswa, atas pertanyaanpertanyaan yang disediakan pada materi kuesioner aplikasi, diperoleh skor sebagaimana yang terlihat pada Tabel 5.

Berdasarkan Tabel 5, sebanyak $78 \%$ responden menyatakan adanya kemudahan proses registrasi dan update profilnya. Lebih dari $70 \%$ menyatakan bahwa tampilan aplikasi, proses akses modul, materi dan uji coba simulasi ujian mudah dioperasikan dan mendukung persiapan ujian HSK seperti yang terlihat pada item no. 2 sd 8 , kecuali no. 6. Pernyataan item 6 , terkait dengan tingkat kepercayaan responden terhadap ujian HSK yang sebenarnya dengan mengacu pada skor aplikasi ini menunjukkan bahwa $63 \%$ menyatakan sesuai dengan level ujian. Namun demikian secara keseluruhan menunjukkan bahwa aplikasi ini cukup signifikan untuk digunakan sebagai media pendukung dan persiapan untuk ujian HSK, yang dinyatakan skor rata-rata untuk semua item sebesar $73 \%$. Sementara berdasarkan tanggapan kontributor yaitu 3 orang dosen program studi bahasa Mandarin, menyatakan bahwa media ini signifikan untuk dijadikan sebagai media bantu untuk latihan dan bahan persiapan ujian HSK mahasiswanya untuk studi lanjut ke PT yang menggunakan bahasa skala Likert 1 - 5. Media aplikasi yang dihasilkan yang Mandarin sebagai bahasa akademis atau pengantar kuliah, dengan skor rata-rata $82 \%$ atau 4,11 dari rentang memberikan fasilitas simulasi ujian secara online, berbeda dengan kajian hasil simulasi HSK sebelumnya yang dilakukan secara manual (Pauw dan Noviana, 2014)(Budianto \& Laurencia, 2014). Dengan memanfaatkan simulasi ujian sampel HSK (HSK mock test) berbasis online peserta akan terbiasa dengan sistem ujian HSK berbasis internet. Peserta tes dapat mengenal dan memahami pola serta komponen evaluasi ujian HSK yang sebenarnya, sehingga dapat mengurangi dampak negatip peserta ujian yang tidak familiar sistem ujian online (Dewi, 2014).

\section{KeSIMPULAN}

Berdasarkan hasil pembahasan yang telah dijelaskan dimuka, dapat ditarik beberapa kesimpulan. Sertifikasi HSK digunakan sebagai salah satu persyaratan yang harus dimiliki oleh seorang yang ingin melanjutkan studi ke pergururan tinggi yang menggunakan bahasa Mandarin sebagai bahasa pengantar kuliah.

Aplikasi SMK untuk mendukung ujian HSK yang dihasilkan dari penelitian ini merupakan model yang dapat digunakan sebagai media mempersiapkan ujian HSK yang sebenarnya. Dari hasil pengujian baik secara fungsional maupun nonfungsional menunjukkan bahwa aplikasi SMK untuk HSK secara signifikan dapat digunakan dengan baik dan sesuai kebutuhan pengguna.

Tabel 5. Umpan balik Responden terhadap aplikasi SMK HSK

\begin{tabular}{|c|c|c|c|c|c|c|c|}
\hline \multicolumn{2}{|r|}{ Aspek yang dievaluasi } & \multicolumn{5}{|c|}{ Skor } & \multirow{2}{*}{$\begin{array}{c}\text { Persentase } \\
(\%)\end{array}$} \\
\hline No & Pernyataan & 1 & 2 & 3 & 4 & 5 & \\
\hline 1. & Kemudahan proses registrasi user dan update profilnya & & & 7 & 19 & 4 & 78 \\
\hline 2. & $\begin{array}{l}\text { Tampilan isian form dan fitur website bersifat mudah dipahami } \\
\text { dan digunakan (user friendly) }\end{array}$ & & 2 & 5 & 17 & 6 & 78 \\
\hline 3 & $\begin{array}{l}\text { Kemudahan user mengakses (baca, unduh, atau cari) konten } \\
\text { yang disediakan. }\end{array}$ & & 2 & 4 & 22 & 2 & 76 \\
\hline 4. & $\begin{array}{l}\text { Materi atau bahan ujian HSK sesuai dengan kebutuhan ujian } \\
\text { HSK level 1-6 }\end{array}$ & & 3 & 11 & 13 & 3 & 71 \\
\hline 5. & $\begin{array}{l}\text { Simulasi ujian HSK tiruan mendukung persiapan user pe serta } \\
\text { menghadapi ujian HSK level } 1-6\end{array}$ & 1 & 2 & 9 & 16 & 2 & 71 \\
\hline 6 & $\begin{array}{l}\text { Tingkat kepercayaan peserta lulus ujian HSK level } 3-6 \text { jika } \\
\text { berhasil lulus ujian HSK tiruan pada level yang sama }\end{array}$ & 2 & 6 & 10 & 10 & 2 & 63 \\
\hline 7 & Modul / Fitur apli kasi \& Interaksinya mudah dioperasikan & 1 & & 9 & 18 & 2 & 73 \\
\hline 8. & $\begin{array}{l}\text { Aplikasi keseluruhan mudah dioperasikan dan bisa digunakan } \\
\text { mengukur kemampuan peserta dalam persiapan ujian HSK }\end{array}$ & & 1 & 8 & 20 & 1 & 74 \\
\hline & Rata-rata & & & & & & 73 \\
\hline
\end{tabular}


Berdasarkan umpan balik yang diberikan responden, secara baik fitur maupun interaksinya aplikasi SMK cukup mudah dioperasikan (user friendly). Secara signifikan peserta meberikan nilai $73 \%$ atau 3,67 skala likert dengan rentang $1-5$. Dengan demikian bahwa media ini dapat digunakan cukup baik untuk mendukung persiapan ujian HSK yang sebenarnya. Media berbasis berbasis online lebih praktis dibandingkan sistem simulasi ujian yang telah dikaji sebelumnya dan bersifat manual (paper-based). Simulasi ujian HSK tiruan yang menyediakan berbagai tipe paket soal yang dibuat oleh admin atau kontributor, memperluas wawasan pengguna mengenal bentuk dan variasi soal standarisasi ujian HSK yang sebenarnya.

\section{Ucapan Terima Kasih}

Terima kasih disampaikan kepada Direktorat Riset dan Pengabdian Masyarakat (DRPM) yang telah memberikan hibah penelitian skema PSN. Berdasarkan hasil penelitian diharapkan dapat dilanjutkan untuk tahapan penelitian berikutnya berdasarkan roadmap yang ada.

\section{DAFTAR PUSTAKA}

AHMAD, F. , 2014. Perbedaan antara Frontend dan Backend. http://afahrurroji.net/, [Diakses : 30 September 2017].

BAMBANG, S.,2016. Study Abroad, China Ranking Three Foreign Student Goals (Studi Luar Negeri, China Peringkat Tiga Tujuan Mahasiswa Asing [Online], http://kabar24.bisnis.com/read/20160417/255/5 38754/, [Diakses : 20 April 2016].

DARMANTO, HARI, Y, dan HERMAWAN, B., Mobile Learning Application to Support Mandarin Language Learning for High School student. Imperial Journal of Interdiciplinary Research., Vo. 2, No. 4,. ISSN: 2454-1362 [Online],

Tersedia: http://www.onlinejournal.in, [Diakses: 20 Maret 2016].

DARMANTO, YULIUS H., DAN BUDI H., "Model Rancang Bangun Sistem Manajemen Konten Bahasa Mandarin untuk Mendukung Standarisasi Ujian Hanyu Shuiping Kaoshi berbasis Android" in Prosiding Seminar Nasional Pendidikan Biologi dan Saintek, (SNPBS II) UMS, ISSN 2527-5333X, 2017.

DARMANTO, HARI, Y., \& HERMAWAN, B., 2015. Rancang Bangun Media Pembelajaran Bahasa Mandarin Berbasis Mobile Learning. Jurnal Nasional Pendidikan Teknik Informatika (JANAPATI), 4(1), 1-6.

DEWI S., 2014. Dampak positif dan negatif tes HSK online.

[Online], https://dewisulistyowati2512.wordpress.com/ca tegory/tes-hsk/ [Diakses : 16 September 2017].

LUTHFI, S., 2018. Perancangan Sistem Berorientasi Objek Dengan UML, https://www.academia.edu/19262530/Perancan gan_Sistem_Berorientasi_Objek_Dengan_UM L, [Diakses Januari 2018].

OLSON, P., 2007. PHP Manual. PHP Documentation Group. America

PAUW B. DAN NOVIANA L., Keterkaitan new HSK dan kurikulum bahasa Mandarin di perguruan tinggi. Jurnal LINGUA CULTURA Vol.8 No.1,hal. 16-21, May 2014.

PRESSMAN, R.S. \& MAXIM, B.R., 2015.Software Engineering: A Practitioner's Approach. Eighth Edition., Mc Graw Hill.

SU, Y. \& SHIN, S., 2015. Test Review HSK. Iranian Journal of language Testing. Vol. 5 No.2. Oktober 2015. ISSN 2251-7324.

Uwika-mandarin.com [Online], 2017., Tersedia di http://www.uwika-mandarin.com/. [Diakses: 7 Oktober 2017].

XIE, F. (2017). Harian Kompas: China Tawarkan 200 Beasiswa [Online]. http://id.chinaembassy.org/indo/gdxw/t1446801.htm, [Diakses : 29 September 2017].

yiiframework.com., 2017. Yii Framework website [Online], Tersedia di http://www.yiiframework.com/, [Diakses: 30 September 2017].

YUDHA, AULIA. (2016). Pengenalan sistem manajemen konten. https://developers.kudo.co.id/2016/09/15/,

[Diakses : Sept. 28, 2017].

YULIAN, F, SUPRIANTO, WIWIK, S., Game simulasi wirausaha berbasis model pembelajaran eksperiensial sebagai alternatif media pembelajaran di smk kelas XI. Jurnal Teknologi Informasi dan Ilmu Komputer (JTIIK) Vol. 2, No. 1, hal. 59-66, April 2015. 
Halaman ini sengaja di kosongkan 